\title{
Sköpun í stafrænum heimi: Sjónarmið myndmenntakennara
}

\author{
Sigríður Ólafsdóttir, Rannveig Björk Porkelsdóttir og Hanna Ólafsdóttir \\ Abstract Um höfundana About the authors Heimildir
}

Markmið rannsóknarinnar var að kanna notkun snjalltækja í listgreinum. Í ljósi aukinnar notkunar snjalltækja í skólastarfi og mikilvægis skapandi hugsunar er leitast við að kanna hvernig slík tæki eru notuð í myndmenntakennslu. Jafnframt er markmiðið að kanna notkunarmöguleika tækninnar í myndmennt og tækifæri til sköpunar. Í rannsókninni var notuð eigindleg rannsóknaraðferð og tekin hálfopin viðtöl við fjóra myndmenntakennara og einn margmiðlunarkennara sem starfa 1 grunnskólum á höfuðborgarsvæðinu. Tilgangurinn var að svara eftirfarandi rannsóknarspurningum: Hver er tilgangurinn með notkun snjalltækja í myndmennt, hvernig nota kennarar tækin í kennslu og hver eru tækifærin til sköpunar? Í pessari grein eru skoðuð viðhorf kennara til tækninnar og snjalltæki sem verkfæri skoðuð. Niðurstöður leiddu í ljós að snjalltæki eru notuð sem tiltekin verkfæri í myndmenntakennslu en pau nýtast nemendum við upplýsingaleit, hugmyndavinnu og efnisleit. Notkun snjalltækja kemur ekki í staðinn fyrir hefðbundnar aðferðir í myndmennt heldur er meginhlutverk peirra að styðja vinnuferli og verkefni nemenda. Drátt fyrir takmarkaða notkun snjalltækja í myndmennt og ólík viðhorf kennara til notkunar tækninnar í greininni gefa niðurstöður til kynna að upplýsingatækni og gagnvirkir miðlar geti eflt skapandi hugsun nemenda. Færni nemenda til sköpunar og pekking peirra á tækninni gegnir par stóru hlutverki. Í myndmennt geta skapast tækifæri fyrir kennara til að breyta kennsluháttum sínum með pví að nýta snjalltæki á virkan hátt við ný verkefni sem annars væru óframkvæmanleg. Pannig getur tæknin bæði nýst til að breyta nálgun og stutt hefðbundnar aðferðir.

Efnisord: Myndmennt, sköpun, snjalltæki, listgreinar, listkennsla.

\section{Inngangur}

Í síbreytilegu samfélagi reynir á margvíslega hæfni nemenda á sviði sköpunar og tækninotkunar. Samkvæmt Aðalnámskrá grunnskóla er sköpun pað að uppgötva, njóta, örva forvitni og áhuga, virkja ímyndunarafl og leika sér með möguleika. Sköpun er að sjá fyrir pað óorðna og framkvæma pað. Degar talað er um tæknina í pessari grein er átt við upplýsingatækni á netinu og stafræna miðla með hljóði og mynd. Markmið greinarinnar er að lýsa notkun snjalltækja í kennslu myndmenntar. Í pví samhengi verður reynt að varpa ljósi á tilganginn með notkun snjalltækja og skoða hvort pau eiga erindi í myndmennt. Leitað var svara við eftirfarandi rannsóknarspurningu: Hver er tilgangurinn með notkun snjalltækja í myndmennt, hvernig nota kennarar tækin í kennslu og hver eru tækifærin til sköpunar? Í Aðalnámskrá grunnskóla er kveðið á um að skólakerfið undirbúi nemendur fyrir pátttöku í flóknu samfélagi sem krefst pess að peir pjálfi almenna námshæfni til að takast á við ýmis verkefni í framtíðinni (Mennta- og menningarmálaráðuneytið, 2013). Í pví 
ljósi er mikilvægt að nemendur fái tækifæri til að afla sér pekkingar eftir margvíslegum leiðum í örvandi námsumhverfi.

Í daglegu lífi reynir á skapandi hugsun einstaklingsins sem felst í pví að rannsaka og skoða nýjar leiðir og setja hlutina í samhengi pannig að peir hafi merkingu. Nemendur virkja ímyndunaraflið og finna hæfileikum sínum farveg í skapandi starfi og pví er sköpunin sjálf afar mikilvægur páttur í námi nemenda (Mennta- og menningarmálaráđuneytið, 2013).

Degar fjallað er um snjalltæki í pessari grein er átt við spjaldtölvur og snjallsíma. Á síðustu árum hefur notkun snjalltækja aukist verulega í samfélaginu, sem og í skólastarfi. Skráning safnaeignar listasafnanna er t.d. komin langt á veg og með pverfaglegum gagnagrunnum eins og Sarpi, sem er menningarsögulegt gagnasafn, eykst gildi upplýsinga með auknu aðgengi sem snjalltækin veita. Aukin próun er einnig í gagnvirkri framsetningu efnis par sem notendur síðna eru virkjaðir til pátttöku. Ithel Jones og Young Park (2015), hafa fjallað um áhrif tækninýjunga í menntun. Dau benda á að ör próun og tæknilegar breytingar hafi leitt til pess að Netið og stafrænir miðlar séu orðnir pættir í daglegu lífi barna og pað auðveldi aðgengi að alls kyns efni sem auki kunnáttu peirra og færni. Pá tala Jones og Park (2015) einnig um að ýmsir notkunarmöguleikar á Netinu og forrit hafi jákvæð áhrif á menntun og proska barna, en rannsóknir á pessu efni eru af skornum skammti. Ekki er hægt að segja til um hvernig notkun tækninnar verður háttað í framtíðinni en ætla má að upplýsingatækni og stafrænir miðlar muni gegna sífellt stærra hlutverki. Ferli skapandi hugsunar og áhrif listmenntunar geta par haft sitt að segja.

\section{Hlutverk og áhrif listmenntunar}

Ýmsar kenningar hafa verið settar fram um hlutverk og áhrif lista í lífi einstaklingsins en hér verður einkum fjallað um hugmyndafræði nokkurra fræðimanna og sameiginlegar áherslur peirra. Samkvæmt Elliot Eisner (2002) eiga nemendur að fá tækifæri til að öðlast betri sjálfspekkingu í gegnum listir. Jafnframt leggur hann áherslu á að peir fái að próa eigin hugsanir byggðar á eigin reynslu. Hann talar enn fremur um að listmenntun hafi mótandi áhrif á hugarfarið og að hún hjálpi einstaklingnum að uppgötva sjálfan sig.

Eisner (2002) hélt pví fram að stöðug upplifun einstaklingsins á umhverfinu mótaðist af menningu, tungumáli, viðhorfum og gildum. Hann taldi að reynsla einstaklingsins væri háð bæði persónulegum og menningarlegum páttum sem próuðust í gegnum skynfærin. Viðhorf Eisners á margt sameiginlegt með hugmyndum Johns Dewey sem hélt pví fram að menntun pyrfti að byggjast á persónulegri reynslu einstaklingsins (Dewey, 1938/2000). Hann hélt pví fram að list væri hluti af lífinu og að venjulegt fólk gerði sér oft ekki grein fyrir pví að list er samofin hinu daglega umhverfi. Dannig verði list að reynslu sem móti einstaklinginn, en pað að öðlast reynslu geti dýpkað skilning og vakið upp tilfinningar eins og ánægju (Dewey, 1938/2000). Einstaklingurinn geti pannig haft áhrif á eigin sjálfsmynd með pví að próa skynfærin út frá menningarlegum páttum eins og tungumáli, listum og vísindum (Eisner, 2002).

Samkvæmt Eisner (2002) hefur skilvirk listmenntun margvísleg áhrif á nemendur pannig að peir proski með sér færni og viðhorf og telur Eisner að markmiðið með listmenntun sé að stuðla að hæfni nemenda til að próa eigin hugsanir með pví að efla skynjun peirra og ímyndunarafl og beina hæfileikum peirra í ákveðið tjáningarform. Listir hjálpa nemendum að tjá sig og með pví að byggja upp eigin reynslu öðlast peir betri sjálfspekkingu. Góð listmenntun getur skerpt næmni og athygli nemenda og gert раð аð verkum að peir skynji hlutina betur út frá fagurfræðilegu sjónarhorni. Að hvetja nemendur til að tjá sig í gegnum listsköpun getur orðið til pess að nemendur festast í sjálfu sköpunarferlinu án pess að pað hafi einhvers konar markmið. Hins vegar er mjög mikilvægt að listnám hafi ákveðinn tilgang vegna pess að í hinu skapandi ferli verður til hugmynd sem síðan birtist í gegnum miðilinn eða efnið sem er notað (Eisner, 2002). Dewey (1934/1980) hélt pví fram að list væri sampætt veruleikanum en við skynjuðum hana og nytum á mismunandi hátt. Fagurfræðin birtist með ýmsum hætti en mikilvægast er að manneskjan njóti 
sjálfrar athafnarinnar í stað pess að keppast við að finna einhverja ákveðna lausn. Dewey á par við pað að ferðalagið skipti meira máli en ákvörðunarstaðurinn. Listin hefur pannig alltaf verið veigamikill páttur í skipulegu samfélagi og í daglegu lífi (Dewey, 1934/1980). Að sama skapi hélt Eisner (2002) pví fram að listir hentuðu vel til að uppgötva sjálfan sig og að pær snerust ekki einungis um einhvers konar afurð eða flutning, heldur gegndu pær mikilvægu hlutverki 1 lífi einstaklingsins og hjálpuðu til við leit að merkingu, efldu undirmeðvitundina og mótuðu hugarfarið (Eisner, 2002). Af pessu má ljóst vera að listnám gegnir mikilvægu hlutverki í daglegu lífi nemenda. Í gegnum listir fá nemendur tækifæri til að rækta ímyndunaraflið, tjá reynslu sína og tilfinningar. Pá geta listir hjálpað nemendum að finna hæfileikum sínum farveg og pað eykur lífsgleði peirra og sjálfspekkingu. Í kenningum Deweys eru hugtökin reynsla og menntun afar áberandi og heldur hann pví meðal annars fram að list sé reynsla sem mótar einstaklinginn. Pá hafa kenningar Deweys haft áhrif á hugmyndir Eisners um að reynsla sé einnig hád persónulegum og menningarlegum páttum.

Í Aðalnámskrá grunnskóla eru skilgreindir sex grunnpættir menntunar sem eiga að einkenna allt skólastarfið (Mennta- og menningarmálaráðuneytið, 2013). Dessir pættir eru: læsi, sjálfbærni, heilbrigði og velferð, lýðræði og mannréttindi, jafnrétti og sköpun. Út frá pessum páttum hafa verið settir fram nokkrir áherslupættir sem hafa skal að leiðarljósi í allri menntun og starfsháttum grunnskóla. Meðal peirra fjölmörgu pátta sem snúa að sköpun er að leggja skal áherslu á frjótt starf, verklega færni og nýsköpun (Mennta- og menningarmálaráðuneytið, 2013). Degar nám á sér stað vinnur einstaklingurinn með fyrri pekkingu til að geta skapað nýja. Menntun er pess vegna viss sjálfssköpun eða leið einstaklingsins til að verða „meira í dag en í gær“ (Menntaog menningarmálaráđuneytið, 2013). Sköpunarprá á rætur í meðfæddri forvitni og stuðlar að frumkvæði einstaklingsins að pví að fara út fyrir mengi hins pekkta. Dá leiðir sköpunargleði til námsáhuga pegar einstaklingurinn skynjar merkingu og gildi viðfangsefnanna. Sem grunnpáttur er sköpun ekki bundin við listgreinar fremur en aðrar námsgreinar og námssvið (Mennta- og menningarmálaráðuneytið, 2013). Hugtakið sköpun merkir að gera eitthvað nýtt eða öðruvísi, glíma við viðfangsefni og finna lausn á peim. Samkvæmt Aðalnámskrá grunnskóla er petta pví ákveðið ferli: „Sköpun er að uppgötva, njóta, örva forvitni og áhuga, virkja ímyndunarafl og leika sér með möguleika. Sköpun er að sjá fyrir pað óorðna og framkvæma pað“ (Mennta- og menningarmálaráðuneytið, 2013, bls. 24). Sköpunarferlið skiptir ekki síður máli en afrakstur verksins en pá leikur einstaklingurinn sér með möguleikana og beitir gagnrýnni hugsun. Sem grunnpáttur menntunar í skólastarfi stuðlar sköpun að fjölbreyttum kennsluaðferðum og vinnubrögðum. Dá brýtur sköpun upp hefðbundin mynstur og veitir nýja sýn á viðteknar hugmyndir.

Í skapandi starfi getur nemandinn haft mótandi áhrif á umhverfi sitt og menningu par sem listir og handverk eru samtvinnuð daglegu lífi. Til pess að geta leyst hin ýmsu vandamál í framtíðinni er mikilvægt að pjálfa skapandi hugsun; pað hefur gildi fyrir einstaklinginn sjálfan og samfélagið 1 heild (Mennta- og menningarmálaráduneytið, 2013).

Allir hafa hæfileika til að skapa. Í list- og verkgreinum fá nemendur aðstæður og margvísleg tækifæri til að proska pann hæfileika, dýpka hann og tileinka sér leiðir til að koma sköpun sinni í verk. Í skapandi starfi fá nemendur tækifæri til að virkja og efla ímyndunarafl sitt, pjálfast í að taka ákvarðanir par sem peir vega og meta mismunandi valkosti og sjá afleiðingar af vali sínu. Nemendur proskast í samvinnu við aðra, efla sjálfstæði sitt og sjálfsspekkingu og finna hæfileikum sínum farveg. (Mennta- og menningarmálaráðuneytið, 2013, bls. 140)

Ken Robinson (2011) er alpjóðlegur leiðtogi á sviði skapandi skólastarfs og nýsköpunar. Starfsvettvangur hans spannar vítt svið, en hann hefur unnið með helstu menningarstofnunum heims. Hann telur að rækta purfi hæfileika mannsins á sviði ímyndunarafls, sköpunar og nýsköpunar til að hann geti tekist á við áskoranir 21. aldarinnar. Robinson (2011) skilgreinir sköpun sem fjölpætt ferli sem felur í sér margs konar færni og aðferðir sem eru ekki einungis 
bundnar við listir. Mikilvægt sé að stuðla að sköpun með mismunandi aðferðum hugans en hún örvi gagnrýna hugsun og veki einstaklinginn til meðvitundar um sjálfan sig og hvetji hann til að leita inn á við. Robinson telur að ímyndunaraflið sé uppspretta sköpunar en pó séu bessi tvö hugtök ekki sami hluturinn. Maðurinn geti séð fyrir sér hluti og athafnir sem hann hafi reynslu af en einnig hluti og athafnir sem aldrei hafi átt sér stað né séu til í raunveruleikanum. Að vera skapandi feli pað í sér að beita slíkri sýn og hrinda henni í framkvæmd (Robinson, 2011).

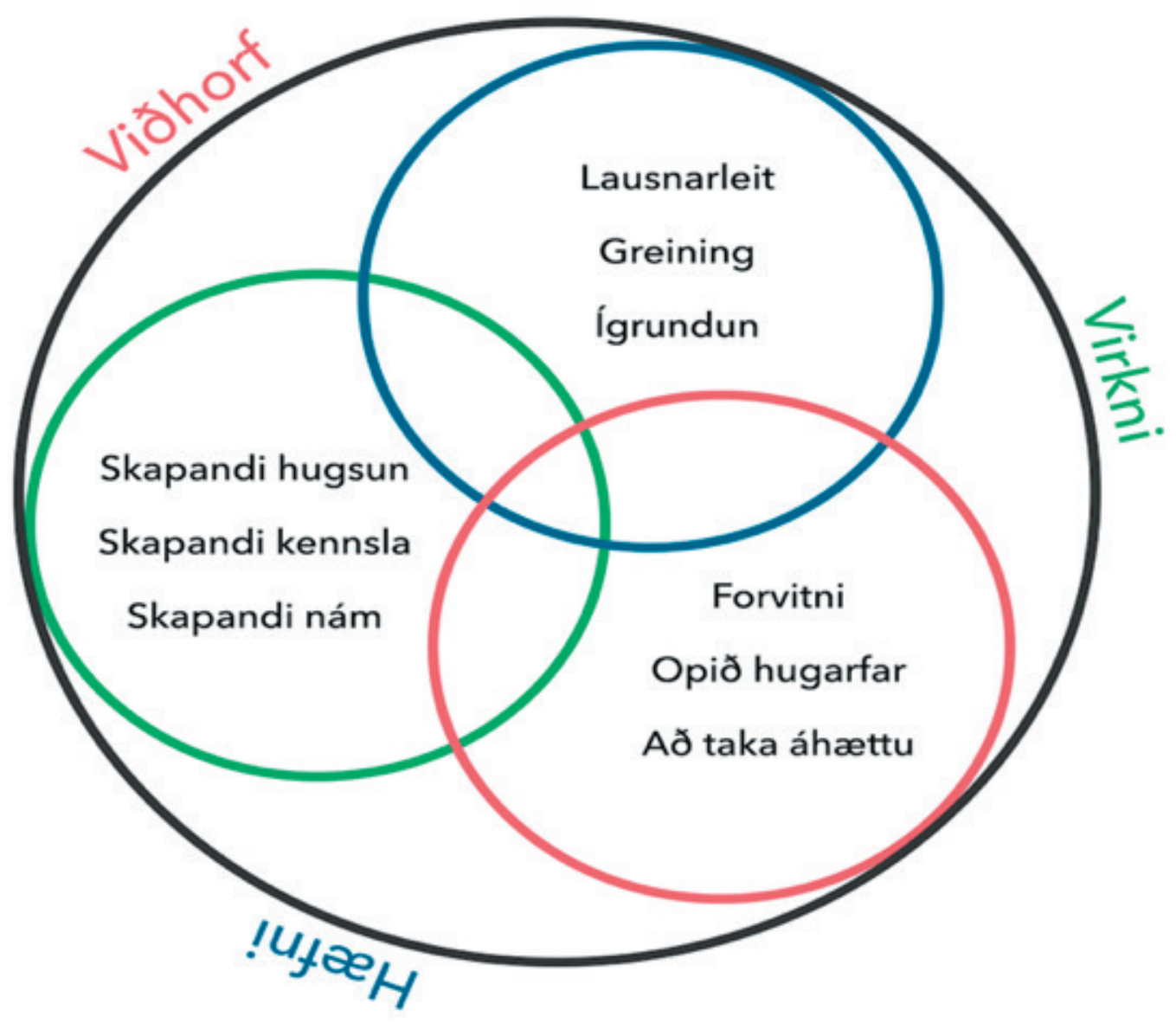

Mynd 1. Ferli skapandi menntunar. Dýtt yfir á íslensku og staðfært af Sigríði Ólafsdóttur (2017) eftir fyrirmynd Tsai (2015).

Á mynd 1 má sjá ferli skapandi menntunar samkvæmt greiningarramma Kuan Chen Tsai (2015), prófessors á sviði lista og hönnunar við Háskólann í Makaó í Kína. Hann lýsir bví hvernig sköpun er samhæft ferli sem byggist á premur óendanlegum víddum: viðhorfi, virkni og hæfni en hver vídd greinist í prjá pæetti. Með viðhorfi er átt við að kennarar skapi hvetjandi aðstæður sem gagnast nemendum, auka forvitni, opna hug peirra og búa pá undir að taka áhættu í leit sinni að pekkingu. Með virkni er átt við pað hvernig skapandi hugsun, skapandi kennsla og skapandi nám birtist í menntun og hvernig pessi nálgun gagnast kennurum í skólastofunni. Pá á priðja víddin аð аðstoða kennara við að ákveða hvers konar hæfni nemendur skuli tileinka sér í námi. Pessi vídd snýr að hæfni nemenda til að leita lausna og leysa vandamál á gagnrýninn hátt par sem peir ígrunda vinnu sína (Tsai, 2015).

Anna Craft (2001) var breskur menntunarfræðingur og prófessor á sviði skapandi skólastarfs. Hún lagði áherslu á sköpunargáfu í menntun til að tryggja farsæla framtíð komandi kynslóða. Hún vildi koma pví á framfæri að einstaklingar byggju við æ minna öryggi í atvinnulífinu sökum breytinga í hagkerfinu og í samfélaginu. Dessar breytingar hafi pær afleiðingar að einstaklingar á 21. 
öldinni verði að öðlast vissa hæfileika til að geta lifað farsælu lífi (Craft, 2001). Hugmyndir Craft (2002) um sköpunargáfu í skólastarfi snúast um pað að efla með kennslufræðilegum aðferðum sjálfstraust barna og hæfileika peirra til að móta eigið líf.. Pá vísar sköpun til vitsmuna barnsins, ímyndunarafls, sjálfssköpunar, sjálfstjáningar og verkkunnáttu. Sköpun á að gera einstaklingnum kleift að stjórna eigin lífi og hún er ekki bundin við einhvers konar afurð eða útkomu (Craft, 2002). Pá taldi Craft (2001) mögulegt að skipta sköpunargáfu í tvo flokka. Annars vegar er pað „stóra c“ (e. high creativity) sem nær yfir snillinga á ýmsum sviðum og hins vegar „litla c“ (e. little creativity) sem á við um áskoranir í hversdagslegum aðstæðum sem kalla á lausnamiðaða hugsun. Í skólastarfi ætti að virkja seinni flokkinn sem á ekki einungis við um pað að takast á við lífið heldur einnig um viðbrögð sem fela í sér virka pátttöku. Að koma auga á vandamál (e. problem identification) og að geta leyst pau (e. problem-solving) eru pess vegna eiginleikar sem mikilvægt er að efla enn frekar í gegnum skapandi leiðir.

Af framangreindu má álykta að sköpun er fjölpætt ferli sem mikilvægt er að pjálfa í skólastarfi. Hugmyndafræði Craft og Robinson um mikilvægi sköpunar byggist á peirri sýn að efla purfi hæfileika einstaklingsins til að takast á við áskoranir 21. aldarinnar. Í Vegvísi UNESCO, sem ætlað er að vera leiðarljós listnáms, kemur pessi sýn einnig skýrt fram: „Meðal mestu áskorana 21. aldarinnar er hin vaxandi pörf fyrir sköpunarkraft og ímyndunarafl í samfélögum sem í vaxandi mæli eru fjölpjóðleg. Listfræðsla getur mætt pessari pörf á skilvirkan hátt" (UNESCO, 2006/2007).

\section{Tæknivæðing í skapandi námi}

Samkvæmt Mennta- og menningarmálaráđuneytinu (2013) er mikilvægt að efla upplýsinga- og miðlalæsi nemenda á sviði upplýsinga- og tæknimenntunar. Nemendur skulu öðlast almenna tæknifærni pannig að peir geti nýtt sér ýmis tæki til fjölbreyttrar úrvinnslu og notað ýmsan tæknibúnað. Pá er einnig mikilvægt að nemendur séu tæknilega læsir og færir um að afla sér pekkingar með tækninni, vinna úr upplýsingum á gagnrýninn og skapandi hátt og greina og meta skilaboð frá ólíkum miðlum (Mennta- og menningarmálaráđuneytið, 2013). I skýrslu á vegum Sambands íslenskra sveitarfélaga um upplýsingatækni í íslenskum grunnskólum kemur fram að á síðustu árum hefur orðið talsverð endurnýjun á tækjabúnaði í skólum en jafnframt eru áætlanir um að fjölga spjaldtölvum fyrir nemendur og kennara enn frekar (Valgerður Freyja Ágústsdóttir, 2013). Pá gaf Reykjavíkurborg (2015) út skýrslu starfshóps sem hafði pað markmið að byggja upp og styðja notkun snjalltækja í skólastarfi. Hópurinn safnaði upplýsingum um stöðu og nýtingu snjalltækja í grunnskólum Reykjavíkur ásamt bví að gera tillögur að leiðum sem hægt væri að miða við í stefnumótun skóla- og frístundasviðs. Í skýrslunni kemur fram að skólinn sé stafrænt umhverfi og að nemendur hafi stöðugan aðgang að námi með tækjum sem hver nemandi geti lagað að sínum pörfum. Meðal annars styður tæknin sampætt, fjölbreytt og skapandi skólastarf par sem allir kennarar eiga pess kost að bæta og próa nám nemenda sinna. Niðurstöður starfshópsins leiddu í ljós að mikilvægt væri að fylgjast með nýjungum í upplýsingatækni og efla próun skólastarfs á tímum tæknivæðingar. Náms- og kennsluumhverfið tekur stöðugum breytingum og búast má við aukinni notkun snjalltækja í skólastarfi. Pví getur reynst nauðsynlegt að hafa pekkingu á kennslufræði og möguleikum tækninnar ef hún á að virka vel í námi og kennslu (Reykjavíkurborg, 2015).

Í Norðlingaskóla hefur innleiðing spjaldtölva í námi og kennslu tekist vel (Sólveig Jakobsdóttir, Skúlína H. Kjartansdóttir, Helga Ó. S. Pórormsdóttir og Ragnheiður L. Pálsdóttir, 2012). Skólinn tók frumkvæði í að próa notkun spjaldtölva í námi og kennslu á unglingastigi á árunum 2012-2013. Skýrsla um innleiðingarferlið sýnir að notkun spjaldtölva gefur kost á pví að vinna með læsi, tæknimiðla og verkkunnáttu á nýjan hátt sem nýtist nemendum vel í framtíðinni. Spjaldtölvuvæðingin leiddi enn fremur í ljós ýmsa möguleika sem nemendur hafa til skapandi starfs en jafnframt aukna pörfá að kanna frekar möguleikana innan list- og verkgreina. Pá sýna niðurstöður skýrslunnar að spjaldtölvur henta vel til að útfæra verkefnin betur, til dæmis eiga 
nemendur kost á pví að nota klippiforrit og einnig forrit fyrir tónlistar- og stuttmyndagerð. Nemendur notuðu spjaldtölvur t.d. við vinnu skólaverkefna og til upplýsingaöflunar en einnig notuðu peir ýmis margmiðlunarforrit og samfélagsmiðla (Sólveig Jakobsdóttir o.fl., 2012).

Á árunum 2012-2013 tók Ómar Örn Magnússon, aðstoðarskólastjóri í Hagaskóla, saman skýrslu um spjaldtölvur í skólastarfi. Par kemur fram að í skólastarfi er mikilvægt að notkun tækninnar bjóði upp á nýjar leiðir í námi nemenda (Ómar Örn Magnússon, 2013). Pá á ekki að nýta tæknina pannig að hún sé aðalatriðið, heldur parf að athuga hvaða tilgangi hún getur pjónað í menntun. Tæknin gerir kröfur um að nemendur vinni hlutina á annan hátt en peir eru vanir sem grundvallast á annars konar hæfni. Dessi hæfni snýr meðal annars að rafrænum samskiptum, miðlun upplýsinga og sköpun. Notkun spjaldtölva í námi fylgja ýmsir möguleikar sem geta undirbúið nemendur betur fyrir framtíðina. En áður en slíkar breytingar í skólastarfi eru gerðar er rétt að íhuga ástæðuna fyrir innleiðingunni. Spjaldtölvur henta vel í einstaklingsmiðuðu námi en pær gegna margvíslegu hlutverki og geta virkað hvar og hvenær sem er. Pá geta spjaldtölvur nýst á vettvangi 1 tengslum við pau viðfangsefni sem eru í gangi hverju sinni og eftir pörfum nemenda. Reynslan hefur sýnt að spjaldtölvur hafa minni áhrif á nám nemenda par sem hefðbundnir kennsluhættir eru ríkjandi. Pá er erfitt að sjá nákvæmlega fyrir hvernig pær geta gagnast nemendum vegna pess hversu fjölbreyttir möguleikar eru í boði. Nemendur uppgötva pess vegna nýjar leiðir á meðan verið er að nota tækin, enda er próunin mjög hröð. Vænlegast er fyrir nemendur að efla með sér færni til að skapa sjálfir í stað pess að vera ávallt viðtakendur eða neytendur upplýsinga (Ómar Örn Magnússon, 2013).

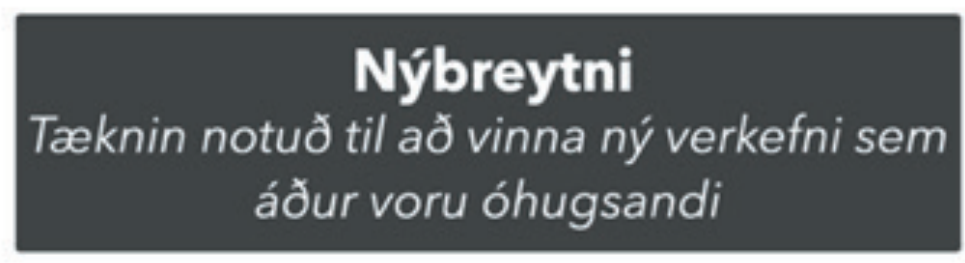

\section{Aə̆lögun}

Notkun tækninnar endurskoðuðog

verkefni unnin á nýjan hátt

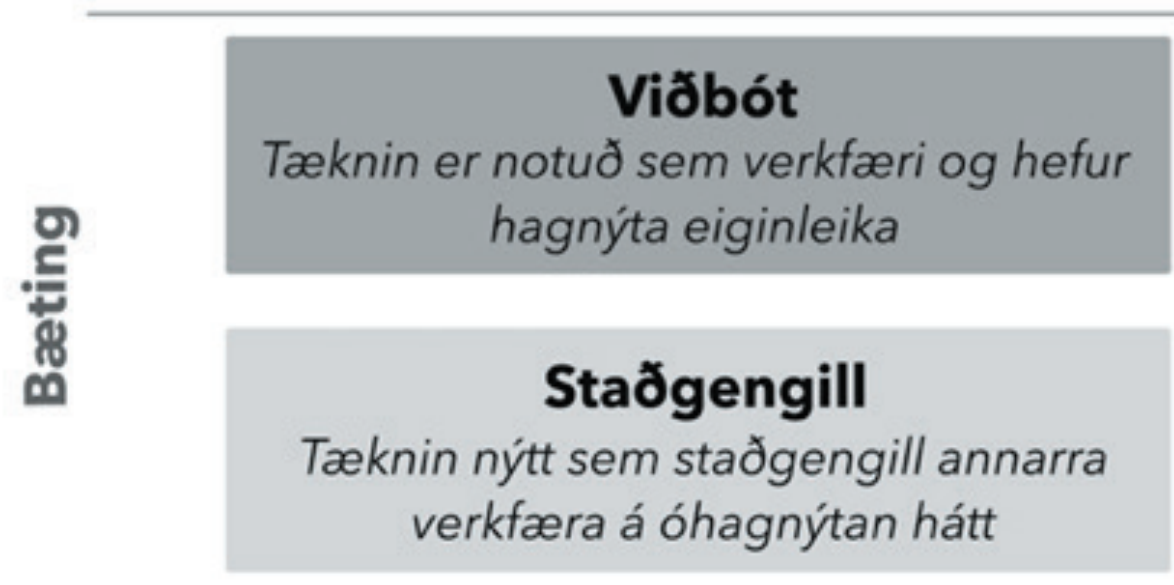

Mynd 2. SAMR-líkanið pýtt yfir á íslensku og staðfært af Sigríði Ólafsdóttur eftir fyrirmynd Puentedura (2014). 
Við innleiðingu nýrrar tækni í skólastarfi getur reynst gagnlegt að hafa í huga SVAN-líkanið (e. SAMR-model) sem Ruben R. Puentedura (2014) próaði en pað skýrir hvernig ný tækni hefur áhrif í námi og kennslu. Eins og sjá má á mynd 2 er aðaláherslan á fyrstu tveimur stigunum að bæa nám og kennslu, en á seinni tveimur stigunum hafa verulegar breytingar á kennsluháttum átt sér stað. Á fyrsta stigi er tæknin notuð á óhagnýtan hátt sem staðgengill án pess að bæta námið á neinn hátt. Á öðru stigi er tæknin notuð sem viðbót eða verkfæri par sem hægt er að nýta ýmsa möguleika. Driðja stigið miðar að pví að notkun tækninnar sé endurskoðuð og verkefni unnin á nýjan hátt. Á fjórða stigi er tæknin notuð til að vinna ný verkefni sem áður töldust óhugsandi án hennar.

\section{Notkun tækninnar í skapandi skólastarfi}

Í niðurstöðum rannsóknar sem Tracy Kwei-Liang Ho og Huann-Shyang Lin (2015) gerðu í Taívan er pví lýst að mögulega geti stafrænir miðlar eflt nám í hefðbundnum listum. Rannsóknin fór fram í grunnskóla í Taipei og notuðu pátttakendur forritið ePainting sem viðbót við hefðbundnar aðferðir. Niðurstöður sýndu að forritið virkaði sem hvati til listsköpunar almennt. Dá benda niðurstöður til pess að að tæknin sé nýtt til að styðja hefðbundnar leiðir en ekki til að fara nýjar, og að bilið á milli stafrænna miðla og hefðbundinna aðferða sé minna en haldið hefur verið fram (Ho og Lin, 2015). Joanna Black og Kathy Browning (2011) hafa fjallað um innleiðingu og notkun stafrænna miðla í listmenntun. Í rannsóknum sínum hafa Black og Browning (2011) komist að pví að nemendur ná góðum árangri í myndmennt ef peim gefst tækifæri til að læra hvernig tæknin getur nýst við próun ýmissa listrænna viðfangsefna. Dær segja að stafræn listmenntun felist ekki eingöngu í pví að læra á nýjan hugbúnað heldur gegni sköpunarpátturinn par lykilhlutverki. Dær lýsa pví jafnframt hvernig efla megi hugmyndir og aðferðir kennara og kennaranema pegar innleiða á stafræna miðla í myndmennt. Pær telja enn fremur að hefðbundnar aðferðir í myndmennt séu grunnurinn að stafrænni listmenntun. Að peirra mati felur tæknin í sér ný tækifæri bæði hvað varðar nám nemenda og sjálfstæða kennsluhætti kennara í takt við breytta tíma (Black og Browning, 2011).

Aðgangur að skapandi verkfærum í gegnum stafræna tækni sem nýtist á ýmsum sviðum innan hönnunar, vísinda og lista er alltaf að aukast. Biophilia er t.d. gott dæmi um skapandi spjaldtölvuverkefni sem unnið hefur verið á vegum Háskóla Íslands og Reykjavíkurborgar í samstarfi við Björk Guðmundsdóttur tónlistarkonu (NordBio, 2014). Par er sköpun sem kennsluaðferð höfð að leiðarljósi til að brjóta upp hefðbundna kennslu á sviði vísinda og lista. Fjöldi kennara hefur sótt námskeið og unnið eftir hugmyndafræði verkefnisins sem hefur раð að markmiði að stuðla að breyttum kennsluháttum og pverfaglegum áherslum (Reykjavíkurborg, 2015).

\section{Rannsóknin}

\section{Markmið}

Markmið með rannsókninni var að kanna notkun snjalltækja í myndmennt. Í rannsókninni var notuð eigindleg rannsóknaraðferð og tekin hálfopin viðtöl við fjóra myndmenntakennara og einn margmiðlunarkennara sem starfa í grunnskólum á höfuðborgarsvæðinu. Tilgangurinn var að svara eftirfarandi rannsóknarspurningu:

Hver er tilgangur snjalltækja í myndmennt, hvernig nota kennarar tækin í kennslu og hver eru tækifærin til sköpunar? 


\section{Pátttakendur}

Við val á viðmælendum var notað tilgangsúrtak og reynt var eftir bestu getu að velja kennara sem hefðu einhverja reynslu og pekkingu á viðfangsefninu sem myndi nýtast rannsókninni. Viðmælendurnir eru allir starfandi grunnskólakennarar með yfir 10 ára starfsreynslu og kenna peir flestir á öllum aldursstigum grunnskólans, fyrir utan einn kennara sem kennir einungis unglingastigi. Fjórar konur tóku pátt og einn karlmaður en peim voru gefin dulnefni í rannsókninni. Tekin voru hálfopin einstaklingsviðtöl við fimm kennara til pess að fá fram mismunandi hliðar á viðfangsefninu.

\section{Framkvæmd}

Alls voru tekin fimm viðtöl og fóru pau fram á vinnustöðum kennaranna. Búinn var til viðtalsrammi með kjarnaspurningum sem fjölluðu meðal annars um reynslu pátttakenda af spjaldtölvum og snjallsímum í myndmennt, viðhorf peirra til tækninnar, upplifun peirra af áhrifum snjalltækjanotkunar á nemendur og hvaða tækifæri peir sæju til sköpunar. Viðtölin voru hljóðrituð með upptökutæki og fóru fram í lok apríl og byrjun maí 2017 á vinnustöðum pátttakenda. Viðtölin voru mislöng, eða 30-60 mínútur, par sem viðmælendur áttu misjafnlega auðvelt með að gera grein fyrir hugsunum sínum og viðhorfum.

\section{Greining gagna og úrvinnsla}

Formleg gagnagreining hófst pegar afritun viðtalanna var lokið. Við úrvinnslu voru viðtölin lesin nokkrum sinnum yfir og samhliða pví var hlustað á upptökurnar eftir pörfum til að öðlast betri skilning. Í framhaldi af pví voru pau flokkuð í ákveðin pemu, svo sem hjálpartæki, upplýsingaleit, að fara nýjar leiðir og sköpun, með pví að gefa peim heiti, en pað er kallað að kóða (e. coding) (Sigríður Halldórsdóttir, 2013).

\section{Niðurstöður}

\section{Viðhorf kennara til tækninnar og reynsla peirra}

Svala og Inga eru mjög jákvæðar gagnvart notkun upplýsingatækni og snjalltækja, en pær hafa báðar lært grafíska hönnun. Svölu finnst skemmtilegt að nota tækin í kennslu til listsköpunar en segist ekki nota snjallsíma nema pá fyrir eldri nemendur. Hún heldur pví fram að snjalltæki séu áhugaverður vinkill í kennslunni og að pau auki möguleika nemenda. Hún bendir á að nemendur séu almennt spenntir fyrir snjalltækjum en peim finnist pó skemmtilegra að vinna beint í höndunum. Ástæðan fyrir pví að hún notar tækin er sú að henni finnst pau mynda skemmtilega tengingu í náminu en einnig nýtist pau til að brjóta upp kennsluna. Hún segir:

Detta er bara svona svolítið skemmtileg tenging / ... / líka bara ég meina, bara nútímalegt, bæði áhugavert, vinna í höndunum. Börnunum finnst reyndar yfirleitt meira áhugavert að vinna í höndunum. En peim finnst petta spennandi, petta er skemmtilegt uppbrot, pú veist ... skemmtilegt að nýta sér petta.

Ingu margmiðlunarkennara finnst frábært að nota tæknina almennt í kennslu og er mjög hlynnt pví að nota hana í námi nemenda. Sjálf hefur hún séð miklar framfarir hjá nemendum sem eiga í erfiðleikum með námið. Hún segir:

Fyrir krakka sem eiga við sértæka námserfiðleika að stríða, eru á einhverfurófi. Kannski átt erfitt með að skrifa eða ..., pá er petta frábær miðill. 
Inga segist vera hrifin af pví sem hún hefur verið að nota með nemendum, eins og t.d. að geta tekið upp myndband, talað inn á tækin og notað pau sem myndavélar.

Dóra segist hafa meiri áhuga á bví að láta nemendur vinna í höndunum en með tækjum. Hún telur sig hafa takmarkaða reynslu af snjalltækjum í kennslu og nefnir í pví sambandi að hún gefi sér ekki nægan tíma til að læra nógu vel á pau. Henni finnst skemmtilegra að vinna beint með efniviðinn í myndmennt og vill leggja meiri áherslu á pað á pessum vettvangi.

Ég veit ekki hvort ég hafi myndað mér einhverja skoðun á pví, en mér finnst petta [myndmenntakennslan] vera svolítið vettvangur til að koma bara og gera eitthvað með höndunum, hérna. Ekki að fara í tölvurnar.

Hún segist ekki finna fyrir sérstakri löngun til að kenna í gegnum tölvur og telur notkunina vera meiri á öðrum svæðum innan skólans og inni á heimilum.

María tekur í sama streng og segist taka eftir pví að snjalltæki séu mikið notuð í öđru skólastarfi. Hún segist vilja standa vörð um handverkið og leggur áherslu á að vinna beint með efniviðinn í myndmennt. Hún segir:

... pað er kannski eina vígið sem eftir er í skólunum til pess að koma við alvöru efni. Fá að leira, fá að mála, fá að vinna með spýtur og allt petta.

María segist ekki heldur vita í hvaða tilgangi spjaldtölva myndi nýtast pegar komi að efnispekkingu, sem einungis sé hægt að öðlast með höndunum.

Hún segist aðallega nota snjallsíma í kennslu ef nemendur vantar upplýsingar eða hugmyndir og segist alls ekki vera á móti tækninni. „En hún má ekki vera ráđandi, finnst mér“.

Jón segist hvorki nota upplýsingatækni né snjalltæki eins mikið núna og hann gerði áður. Hann segir að spjaldtölvur geti verið skemmtilegur og frábær miðill en að hann hafi upplifað marga tæknilega hnökra hvað varðar gagnamagn og flutning. „Pannig að svona vandamál tóku allt of mikla orku og mikinn tíma." Hann segist hafa fengið mikinn áhuga á tölvum fyrir nokkrum árum en pá hafi farið mikil vinna í tæknina sjálfa. Hann bendir á að hugmyndin um aukna notkun upplýsingatækni í skólum sé oft á pá leið að hún eigi einhvern veginn að „bjarga menntuninni“. „En mér finnst petta allt snúast í rauninni um innihald, sko“. Jóni finnst manneskjur skipta meira máli og leggur áherslu á myndlæsið og listina fremur en tæknina. Hann telur að eigi að nota tæknina í myndmenntakennslu pá verði kennarar að búa yfir ákveðinni færni til að hún nýtist sem best. Í pessu sambandi segir hann:

Detta snýst líka bara um pað að maður sé ekki að dreifa kröftum sínum of mikið sko. Рað eru fullt af listamönnum að vinna með stafræna list. Og pá má spyrja sig, ætlum við að fara pangað í myndmenntakennslu. Og pá er pað eins og ég segi ... pá er pað bara einn miðill, en vandinn við pennan miðil er sá að til pess að pað verði eitthvað vit í pví pá purfa menn að kunna petta og skilja petta.

Af máli viðmælendanna má greina misjöfn viðhorf til tækninnar og tækni almennt í listgreinum. Viðmælendurnir voru allir á sama máli um að snjalltæki væru fyrst og fremst verkfæri eða rannsóknartæki sem kæmu að góðum notum í myndmennt pegar nemendur pyrftu að leita sér upplýsinga, fá hugmyndir eða ná sér í efni til að vinna með. Myndmenntakennararnir virðast allir leggja fyrst og fremst áherslu á myndlist og pá grunnpæetti sem nemendur eiga að tileinka sér. Eins voru viðmælendurnir meðvitaðir um pá kosti og galla sem fylgja pví að nota snjalltæki jafnt sem upplýsingatækni í kennslu. Flestir telja að snjalltæki hafi margt fram að færa hvað varðar fjölbreytt verkefni og hugmyndir og eru almennt jákvæðir gagnvart eiginleikum tækninnar. 


\section{Snjalltæki sem verkfæri}

Svala segir að nemendur noti spjaldtölvur og snjallsíma helst í upplýsingaöflun í upphafi verkefna pegar peir eigi t.d. að finna upplýsingar um listamann, finna myndir eða vinna með texta.

Við eigum 15 spjaldtölvur sko, ekki við sér samt pví miður en oft hefjum við verkefnin á að pá purfa pau, peim er sagt að pau eiga að leita og pá fara pau í að leita að einhverju en svo er pað líka oft bara sjálfsprottið af pví að pau vilja leita og biðja pá um spjaldtölvur til að ... eða pá nota símana sína, pessi elstu í unglingadeildinni.

Svala segir einnig að nemendur noti spjaldtölvur til að vinna fjölbreytt verkefni í ýmsum forritum eins og við myndvinnslu og hreyfimyndagerð. Бað sé mismunandi eftir aldri hvað nemendur geri en hún segir að peir yngstu hafi t.d. prófað að mála í tölvunum og að pá hafi kennslan verið í samræmi við grunnpætti í myndlist. „Detta er bara verkfæri en hefur, skilurðu ... nýta sér sko grunnpætti myndlistarinnar eins og pau væru í myndlist. En í staðinn fyrir að nota pensla pá nota pau spjaldtölvu og penna, af pví að við erum með spjaldtölvur sem eru með penna og pau geta nýtt sér pað." Svala gerir greinarmun á pví að nota snjalltæki annars vegar og upplýsingatækni hins vegar en segir að notkunin skarist oft. Hún segir að nemendur nýti sér upplýsingatækni við verkefni sem peir eru að vinna með í spjaldtölvunum, t.d. í myndvinnslu. „Баð blandast smá kannski. Upplýsingatæknin er pá meira pannig að pú ert að leita pér upplýsinga og finna, viða að pér efni.“ Í sambandi við að nota forritin í spjaldtölvunum segir hún: „,É er sem sagt, pá er snjalltækið orðið að öðru. Pá er pað orðið bara eins og pappír með fullt af verkfærum, í staðinn fyrir, pú ert annars vegar bara að leita pér að upplýsingum. Mér finnst petta svona tvískipt.“

Póra er á sama máli og Svala varðandi notkun snjalltækja í myndmennt og segir að nemendur fái gjarnan leyfi til að nota pau í verkefnavinnu. „Hvort sem pau eru með spjaldtölvur eða símana sína, pú veist, pau spyrja bara hvort pau megi nota símann sinn í staðinn fyrir iPadana sem ég er með og nýta pað ef pau purfa að leita að einhverju eða fá eitthvað svona frekari hugmyndir“. Hún segir að tækin henti t.d. í listasögu: „Mér finnst gott að nota petta sem gagn, pú veist, pegar verið er að leita uppi myndir eftir einhverja listamenn og skoða svona listasögu og eitthvað svoleiðis, pað er svo rosa mikið til á netinu af pví, og sjá, pú veist ... mér finnst pad rosa gott.“ Pá segir hún að nemendur skoði og lesi um ýmsa listamenn á netinu sem tengjast verkefnum peirra og vinni síðan í anda pess listamanns sem peir velja sér. „Náttúrulega, kosturinn er pað аð maður bara getur verið kominn á listasafnið einhvers staðar og getur fengið allar myndir sem maður vill og skoðað alla listamenn.“

María segist ekki nota spjaldtölvur í myndmennt heldur noti nemendur frekar snjallsímana sína til að ná sér í upplýsingar eða í hugmyndavinnu. Hún segist hins vegar nota venjulegar tölvur í myndvinnslu og pá eru pær einungis hjálpartæki. María telur pað sama eiga við um snjalltæki:

Detta er bara ein leið til pess að nálgast viðfangsefnið. Myndi ég halda, sem verið er að vinna með. Dú getur nýtt pér pessa tækni sem part af vinnuferlinu, án pess að pað sé markmiðið í sjálfu sér. En pað getur hjálpað og pá er um að gera að nýta sér pað. Pannig finnst mér tölvan og snjalltæknin geta stutt við verkefni, án pess að vera markmið í sjálfu sér.

Inga margmiðlunarkennari lítur einnig á snjalltæki sem verkfæri og finnst pau vera orðin sjálfsagður hlutur í námi nemenda að vissu leyti. „Detta er eitthvað sem gerir gagn. Og pað er hægt að nýta petta á svo margan hátt. Hægt að tengja petta inn í svo margt. Kannski hugsunin að petta sé verkfæri er kannski bara að petta er tæki sem á að nota. Eitthvað svoleiðis." Í skólanum hennar Ingu er mikið um pemavinnu en hún telur snjalltækin vera skemmtilega leið fyrir nemendur til að nota í verkefnum í staðinn fyrir að gera t.d. Powerpoint-kynningu. Hún segir að pá geti nemendur búið til Green Screen með ákveðnu efni og sagt frá. „Đannig að pau geta sagt frá pví sem pau eru búin að læra og tengt pað við myndir." Hún segir einnig að nemendur geti notað eigin teikningar í snjalltækjunum til að lýsa pví sem peir hafa verið að læra. Í pessu sambandi segir hún: 
Раð vantar oft sko, við höfum stundum talað um pað kennararnir, að pau læra eitthvað og pau muna ekkert. Pannig аð kannski að nota svona tæki til pess að pau geti endursagt. Að pau geti sagt frá í sínum orðum pað sem pau eru búin að læra. Рað kannski svona ætti að geta aukið möguleikana á pví að pau kannski tileinki sér pað eða muni pað.

\section{Snjalltæki sem tæki til sköpunar}

Svala telur að nemendur fái tækifæri til að tjá sig og nýta sköpunarkraftinn sem í peim býr pegar peir vinna í spjaldtölvunum alveg eins og með einhverju öðru verkfæri. Hún segir pó að pað sé jafnframt heftandi að vinna í tækjunum og nemendur séu frjálsari pegar peir vinni beint með efniviðinn pó tæknin bjóði upp á aðra möguleika.

... pau eru spennt fyrir myndlist, pá finnst peim skemmtilegra að vera alveg hands on 1 bara litunum og mála og leira, skilurðu mig?

Maríu finnst tæknin stundum vera hamlandi hvað varðar sköpunarkraft nemenda vegna pess að par eru einungis ákveðnir valmöguleikar í boði. Hún telur að nemendur purfi að vera mjög klárir á snjalltækin til pess að geta unnið með pau á skapandi hátt.

Dað er vissulega hægt en pú parft að vera rosalega skapandi í hugsun til að forritið stjórni pér ekki heldur pú pví. Gerir við pað eitthvað sem er skapandi, pví annars er forritið bara að gera pað sem pað kann.

Hún segist ekki vera viss um að tækin ýti alltaf undir sköpun nemenda nema ef peir eru mjög klárir í að láta snjalltækin gera pað sem peir vilja.

Dóra reynir að stuðla að sköpun með pví að leyfa nemendum að fara ólíkar leiðir og nota ýmsan efnivið. Hún vill að nemendur fái tækifæri til að nýta sínu sterku hliðar og reynir pess vegna að hafa verkefnin fjölbreytt. Hún telur að með snjalltækjum opnist heill heimur af möguleikum fyrir nemendur en henni finnst hins vegar að snjalltæki geti verið heldur flatur miðill pegar vinna á verkefni beint í tækið.

Inga margmiðlunarkennari segist stuðla að sköpun nemenda með fjölbreyttum verkefnum. Hún telur að notkun snjalltækja kveiki áhuga nemenda og pannig sé hægt að taka hlutina aðeins lengra.

Af pví pú ert ekki bara bundinn við blað og blýant heldur lifnar myndin kannski við

Hún telur að notkun tækninnar hafi góð áhrif á ímyndunarafl nemenda og hefur séð margt skemmtilegt gerast, eins og t.d. pegar nemendur eru að vinna hreyfimyndir.

Jóni finnst snjalltæki vera flott verkfæri og segir í pví sambandi: „Detta er bara verkfæri. [...] Og við eigum bara að líta á petta sem verkfæri en ekki sem einhvern nýjan sannleik. Eins og mér finnst oft umræðan vera og, sko, einhvern vegin hæpið í kringum petta." Hann bendir á að ef kennarar ætla að nota tækin í kennslu purfi peir að geta boðið nemendum upp á pannig verkefni að hægt sé að nota tækin á skapandi hátt. „Við notum teiknibretti jafnvel til að teikna í tölvuna og ég veit að pað er hægt að teikna í forritum beint á skjá, t.d. á iPadana“. Hann segist sjálfur hafa prófað að teikna með penna og að myndskreyta bækur með peim hætti og vanist pví vel.

Maður getur teiknað með puttanum pess vegna. Рað er hægt að fá slík forrit, sko. Pá kem ég alltaf aftur að pessu, en af hverju nota ég ekki bara olíupastel. Skilurðu, pað er einhvern veginn pessi glerrúda parna á milli sem er pínu ... og pað er kannski, sko, já, er pað leiðin? Á maður bara að fara í stafræna heiminn alveg, ég veit pað ekki. 
Jón telur að tæknin búi yfir fleiri möguleikum en kennarar geri sér grein fyrir og pað tengist eigin takmörkunum kennara. „Og ég hefði viljað sjá petta kannski dafna á sínum eigin forsendum, einhvern veginn að, pú veist ... mér finnst við ekki alveg vera að nýta tæknina í pað sem hún er best." Honum finnst tæknin fá að njóta sín betur á öđrum vettvangi, eins og t.d. við forritun.

Niðurstöðurnar gefa til kynna að snjalltæki séu einkum notuð sem ákveðið verkfæri í listgreinum og að pað sé aðaltilgangurinn með peim. Svo virðist sem snjalltæki geti stutt vinnuferli nemenda og henti pegar kemur að upplýsingaöflun og hugmyndavinnu. Einnig virðast pau nýtast til að hjálpa nemendum að muna pað sem peir hafa verið að læra. Einn kennarinn er ekki viss um hvort ákjósanlegt sé að auka stafræna notkun í listum og finnst tæknin eiga að fá að njóta sín betur á öðrum vettvangi.

\section{Samantekt}

Myndmenntakennararnir höfðu mismunandi reynslu af notkun tækninnarí námi og kennslu. Tveir peirra tala um að standa vörð um handverkið og hefðbundnar aðferðir og peir telja greinina vera ákveðinn vettvang til pess að vinna í höndunum en ekki í tækjunum. Einn myndmenntakennari sagðist hafa gefist upp á pví að nota tæknina í kennslu og benti á að mikilvægt væri fyrir kennara að vera vel að sér í tækninni ef hún ætti að nýtast í myndmennt. Dá var margmiðlunarkennarinn hlynntur pví að nota tæknina almennt í námi nemenda og sagðist hafa séð miklar framfarir meðal nemenda sem glímdu við námserfiðleika. Að hans mati hafa snjalltæki mikið fram að færa pegar kemur að fjölbreyttum kennsluháttum par sem styrkleikar nemenda fá að njóta sín. Í myndmennt geta skapast tækifæri fyrir kennara til að breyta kennsluháttum sínum með pví að nýta snjalltæki á virkan hátt til nýrra verkefna.

\section{Umræður}

\section{Tilgangur og notkun snjalltakja í myndmennt}

Í viðtölunum kom skýrt fram að kennararnir líta á snjalltæki og almenna tækni fyrst og fremst sem ákveðið verkfæri í kennslu sem aðstoðar nemendur við upplýsingaleit, hugmyndavinnu og við öflun efniviðar. Í peim tilfellum sem kennararnir sögðust hafa notað tæknina var tilgangurinn með pví að styðja við vinnuferli og verkefni nemenda. Dessar niðurstöður eru í samræmi við pá hæfni sem Aðalnámskrá fer fram á að nemendur hafi tileinkað sér við lok 10. bekkjar, en pá eiga nemendur að hafa fengið tækifæri til að nýta sér fjölbreytta miðla og upplýsingar sér til stuðnings í námi sínu (Mennta- og menningarmálaráđuneytið, 2013). Viðhorf kennaranna til snjalltækja og annarra miðla var jákvæett, en peir töldu að listgreinar væri sá vettvangur í skólum par sem nemendur fengju tækifæri til að próa með sér hagnýta færni með hefðbundnum aðferðum og leggja peir pess vegna ríka áherslu á pað.

Jafnframt kom pað glögglega fram í viðtölunum að notkun tækninnar í listum er ekki sérstakt markmið í námi nemenda heldur er mikilvægt að geta boðið nemendum upp á fjölbreytt vinnubrögð. Myndmenntakennararnir sögðu að tæknin væri ekki höfð í forgrunni í námi nemenda en einungis tveir sögðu að gæta pyrfti pess að takmarkaðir eiginleikar tækninnar stjórnuðu ekki verkefnum nemenda og að mikilvægt væri að nemendur gætu notað tæknina pannig að hún pjónaði markmiðum verkefnisins. Pá töldu flestir að nemendur nýttu sér pá grunnpætti sem peir ættu að tileinka sér í myndmennt pegar tæknin væri notuð í verkefnum pó ekki væri lögð sérstök áhersla á pað. Detta er í samræmi við niðurstöður Black og Browning (2011), en að áliti peirra ætti tæknin að gegna minniháttar hlutverki í sjónlistum. Pær telja einnig að áhersla á skapandi kennslufræði skili mestum árangri við innleiðingu tækninnar. Einn kennari talaði um að tæknin byggi yfir fleiri möguleikum en kennarar gerðu sér almennt grein fyrir og pess vegna tengdist notkunin eigin takmörkunum kennara. Einnig kom pað fram í viðtölunum að pað geti reynst kennurum tímafrekt að leita að smáforritum í snjalltækjum par sem mikið framboð er á misgóðu efni. 
Nemendur fá tækifæri til að vinna margvísleg verkefni í myndmennt með notkun snjalltækja par sem peir geta kannað aðra möguleika og skoðað nýjar leiðir. Detta skapandi ferli reynir á ímyndunarafl peirra og frumleika. Pessar niðurstöður eru í samræmi við greiningarramma Tsai (2015) um ferli skapandi menntunar, sem snýst um að draga fram vitræna eiginleika nemenda og stuðla pannig að skapandi námi. Í viðtölunum voru kennararnir á báðum áttum hvað varðar tækifæri nemenda til að nýta sköpunarkraftinn pegar tæknin er notuð. Nemendur verði að vera mjög færir til pess að geta látið snjalltækin gera pað sem peir vilja að pau geri fyrir pá. Samkvæmt niðurstöðum Black og Browning (2011) geta nemendur tjáð sig á skapandi hátt með notkun stafrænna miðla en í pví felst meira en að læra á nýjan hugbúnað. Dær halda pví fram að sköpunarpátturinn sé jafn mikilvægur í stafrænni listmenntun og í hefðbundnum listum (Black og Browning, 2011).

Deir kennarar sem héldu að tæknin hefði hamlandi áhrif á sköpunarkraft nemenda voru á peirri skoðun að hefðbundnar aðferðir í myndmennt stuðluðu frekar að sköpun nemenda par sem peir fengju pannig frelsi til að vinna með alvöru efnivið. Dewey (1934/1980) tengir virkni og proska við reynsluhugtakið, en hann hélt pví meðal annars fram að reynsla einstaklingsins væri mikilvægari en útkoman úr verkefninu. Pá nefndi einn kennari að handverkið og tækin gætu hjálpað hvort öðru og pess vegna gætu nemendur náð sér í upplýsingar í snjalltækjum eða borðtölvum eftir pörfum og unnið í forritum meðfram hefðbundnum aðferðum. Í viðtölunum mátti greina ánægju kennara með upplýsingaflæðið á veraldarvefnum. Tveir kennarar töluðu pó sérstaklega um að á netinu væri til of mikið af efni og að stundum vissu nemendur ekki að hverju peir væru að leita. Pó nemendur verði stöđugt fyrir áhrifum alls staðar frá, pá er mikilvægt að hugmyndir peirra komi frá peim sjálfum og að peir finni fyrir pörf fyrir að vinna verkefnin út frá eigin hugmyndum í staðinn fyrir að apa eftir skemmtilegri hugmynd. Dað fer eftir eðli verkefnisins hvort ímyndunaraflið fær að njóta sín. Black og Browning (2011) komust pannig að peirri niðurstöðu að tæknin hefði ekki slæm áhrif á sköpun og ímyndunarafl nemenda. Einn kennarinn sagðist vilja sjá tæknina dafna á sínum eigin forsendum og að almennt nýttu kennarar ekki tæknina í pað sem hún gagnaðist best til. Hann taldi að möguleikar varðandi sköpun væru meiri ef nemendur gætu notað forritunaraðferðir í sjónlistum og unnið pannig með snjalltækjum að viðfangsefnum sem tengdust hönnun og tæknimennt. Ef nemendur fá tækifæri til að læra forritun geti pað leitt til frekari virkni peirra og eflt pá í sjálfstæðum vinnubrögðum.

\section{Ávinningur og annmarkar}

Niðurstöðurnar gefa til kynna að snjalltæki í myndmennt geti haft bæði hvetjandi og letjandi áhrif pegar litið er til kennslufræðilegra pátta. Eins benda kennararnir á að áhrif snjalltækja og gildi peirra í námi nemenda fari eftir pví hvernig pau eru notuð í verkefnum. Tæknin er í sumum tilvikum nýtt í rannsóknarferli nemenda en einnig eru dæmi um óöryggi nemenda varðandi eigin sköpun. Að mati kennaranna eiga nemendur auðvelt með að tileinka sér tæknina. Hins vegar töluðu peir um að nemendur hefðu oftast meiri áhuga á að vinna beint í höndunum í myndmennt og að langflestir tækju pað fram yfir tæknina. Í pví samhengi töluðu nokkrir kennarar um afturhvarf nemenda til hefðbundinna aðferða vegna pess hversu algeng tæknin er orðin í daglegu lífi. Einn kennari talaði sérstaklega um að nemendur gæetu unnið verkefnin á sínum forsendum í gegnum tæknina par sem styrkleikar peirra fengju að njóta sín. Pá kom einnig fram að nemendur ættu auðveldara með að tileinka sér námsefnið ef peir verkefnin verkefni með hjálp hennar. Аð mati margmiðlunarkennarans er pað mikill kostur ef nemendur geta sagt frá með sínum eigin orðum og pannig henti spjaldtölvur vel til pess að endursegja. ó að pað atriði snúi ekki að myndmennt sýnir pað pann ávinning sem hafa má af snjalltækjum í námi og kennslu, en einnig í skapandi starfi. bá kom fram að nemendur í myndmennt gætu byrjað hugmyndavinnu á blaði eða á teikniborði og síðan fullunnið verkefnin í tölvum. Einnig var bent á að snjalltæki og tölvur gætu boðið upp á ýmis forrit sem stuðluðu að nýbreytni í kennsluháttum. Snjalltæki og aðrar tölvur virðast pannig geta stutt og eflt verkefni nemenda ef pau eru notuð á virkan og skapandi hátt. Detta er í samræmi við pað sem Black og Browning (2011) segja um innleiðingu tækninnar og hvernig hún felur í sér ný tækifæri, bæði hvað varðar nám nemenda í sjónlistum og sjálfstæða kennsluhætti kennara. 
Helstu annmarkar sem komu fram í viðtölum við kennarana voru peir að til pess að tæknin geti orðið nógu skilvirk purfa kennarar að leggja sig töluvert fram við að læra á hana.

Pá bentu peir á að áhugi og frumkvæði kennara skipti hvað mestu máli pegar ákveðið væri að nota tæknina í auknum mæli. Flestir kennararnir töldu að pörf væri á frekari leiðbeiningum. Dá telja peir mikilvægt að kennarar fái aðstoð við að koma sér af stað. Dessar niðurstöður gefa til kynna að myndmenntakennarar hafi áhuga á að kynna sér möguleika tækninnar en jafnframt að pekking margra peirra sé afar takmörkuð. Sá kennari sem hafði mestu reynsluna af notkun tækninnar var einnig sá neikvæðasti sökum tæknilegra hnökra og geymslu efnis. Dessar niðurstöður benda til pess að kennarar séu almennt meðvitaðir um pá kosti og galla sem fylgja pví að nota pessa tækni í kennslu.

\section{Lokaorð}

Hver er tilgangurinn með notkun snjalltækja í myndmennt, hvernig nota kennarar tækin í kennslu og hver eru tækifærin til sköpunar? Niðurstöður benda til pess að notkun tækninnar í myndmennt sé afar takmörkuð er par lögð aðaláhersla á handverk og að nemendur fái tækifæri til að kynnast hefðbundnum aðferðum. Pá benda niðurstöður til pess að pað geti myndast ákveðin togstreita milli tækninnar og hefðbundinna aðferða. Tæknin getur gagnast nemendum við upplýsingaleit, hugmyndavinnu og öflun efniviðar og pví má álykta sem svo að megintilgangurinn með notkun tækninnar í myndmennt sé að styðja vinnuferli og verkefni nemenda. Notkun snjalltækja kemur pess vegna ekki í staðinn fyrir hefðbundnar aðferðir í myndmennt pó fyrir að niðurstöður rannsóknarinnar sýni fram á mikla möguleika á nýtingu tækninnar í greininni. Tækninotkun er ekki einungis hagnýt sem ákveðið verkfæri í listum heldur nýtist hún einnig til nýrra verkefna sem annars væri óhugsandi að framkvæma. Pannig getur tæknin stuðlað að nýbreytni og umbreytingu á kennsluháttum í listgreinum. Almenn tækninotkun á pess vegna fullt erindi í listgreinum eins og í öðrum greinum grunnskólans. Sköpun og tækninotkun eru hvor tveggja mikilvægir pættir í nútíma skólastarfi. Niðurstöður sýna að áhugi og frumkvæði kennara eru pættir sem hafa mikið að segja varðandi notkun tækninnar í myndmennt, en mikil pörf er á aukinni pekkingu kennara á möguleikum hennar í faginu. Skólastarfið er í sífelldri próun og ljóst er að á næstu árum er mikilvægt að fylgjast með tækninýjungum en um leið að auka meðvitund um tilgang peirra og virkni í almennu námi nemenda. Notkun tækninnar í myndmennt kallar á nýjar leiðir, bæði hvað varðar nám nemenda og kennsluhætti kennara. Myndmenntakennarar eiga möguleika á pví að breyta kennsluháttum sínum með pví að nýta snjalltæki með virkum hætti. Mikilvægt er að skólakerfið undirbúi nemendur til að takast á við verkefni framtíðarinnar par sem færni á sviði sköpunar er mikils metin.

\section{Creativity in the digital world: Art teachers' perspectives}

The objective of this article is to draw attention to the use of smart devices in the arts. Due to the increased use of smart devices in schools and the importance of creative thinking, the aim was to shed light on the purpose of smart devices in the arts, focusing on visual art education. This article is based on a master's thesis by Sigríður Ólafsdóttir entitled Creativity in the digital world: Art teacher's perspectives, compiled in the Faculty of Education at the University of Iceland. The goal was also to explore technological possibilities in visual art education and opportunities for creativity. The study used a qualitative research method and conducted semi-structured interviews with four visual art teachers and one multimedia teacher working in elementary schools in Reykjavík. All the teachers were accomplished visual art teachers with over ten years of teaching experience. Data was gathered through conversations and interviews with all five teachers. All the interviews took place in the teachers' schools in April 2017 and lasted from 30 to 60 minutes each. When analysing data, the focus was on interpretive analysis; that is, the researcher tries to understand how meaning 
is created by listening to interviews and reading transcripts to make a theme for the findings. All the teachers were giving fictitious names. The purpose was to answer the following research question: Can smart devices affect the creative thinking of children and young people? What is the purpose of smart devices in the visual arts and how do teachers use these devices in teaching? In this article we look at teachers' attitudes towards smart devices in the visual arts and how they were applied in teaching.

The results revealed that smart devices are used as specific tools in visual art education and they assist students in information retrieval, conceptual work and material acquisition. The use of smart devices does not replace traditional methods in the visual arts, however, since their main purpose is to support students' work processes and tasks. Furthermore, the findings revealed that World Wide Web smart devices can serve as a learning platform to students in art education. Despite the limited use of smart devices in the visual arts and different professional viewpoints of teachers towards the use of this technology, the results indicate that information technology and interactive media can enhance the creative thinking of students. Students' creative aptitude and their knowledge of technology plays an important role. In the visual arts, opportunities can be created for teachers to change their teaching practices by actively using smart devices in new projects that would otherwise be unthinkable. Thus, technology can support traditional methods.

Key words: Visual arts, creativity, smart devices, arts, art education

\section{Um höfundana}

Sigríður Ólafsdóttir (siggola@gmail.com) starfar sem umsjónarkennar á miðstigi. Hún lauk B.Ed.- prófi frá Háskóla Íslands árið 2012 og M.Ed.-prófi í menntunarfræðum frá sama skóla 2017.

Rannveig Björk Dorkelsdóttir (rbth@hi.is) er aðjúnkt við Menntavísindasvið Háskóla Íslands. Hún lauk B.Ed.-prófi frá Háskóla Íslands árið 2003 og MA.-prófi í uppeldis- og menntunarfræðum frá sama skóla árið 2009 og MA.-prófi í hagnýtri menningarmiðlun frá sagnfræði- og heimspekideild árið 2012. Hún lauk doktorsprófi frá Kennaradeild Norska tækni- og vísindaháskólans (NTNU) í Drándheimi 2016, par sem hún fjallaði um innleiðingu leiklistar í grunnskóla á Íslandi. Rannsóknarsvið hennar tengist meðal annars listkennslu og leiklist.

Hanna Ólafsdóttir (hannao@hi.is) er lektor í listgreinum og formaður námsbrautarinnar List- og verkgreinar á menntavísindasviði Háskóla Íslands. Hún lauk prófi frá Myndlistar- og handíðaskóla Íslands (1994), frá Danmarks Designskole 1996, diplóma í heimspeki (á meistarastigi) frá Syddansk Universitet 2010 og útskrifaðist með meistaragráđu frá Listkennsludeild Listaháskóla Islands 2011. Rannsóknarsvið hennar tengist meðal annars listkennslu og menningarfræðum. Hanna vinnur bæði að eigin myndlist og við kennslu.

\section{About the authors}

Sigríður Ólafsdóttir (siggola@gmail.com) works as a classroom teacher in lower secondary school. She completed her B.Ed. degree from the University of Iceland in 2012 and an M.Ed. degree from the same university in 2017.

Rannveig Björk Thorkelsdóttir (rbth@hi.is) is assistant lecturer at the University of Iceland, School of Education. She completed her B.Ed. degree from University of Iceland in 2003, an M.A. degree in Educational Theory in 2009 and an M.A. degree in applied studies in Culture and Communication from the Faculty of History and Philosophy of the University of Iceland in 2012. She holds a Ph.D. from the Norwegian University of Science and Technology (NTNU) with emphasis on drama and theatre study. In her research and practice, she focuses on drama and artistic approaches to teaching and learning. 
Hanna Ólafsdóttir (hannao@hi.is) is Assistant Professor at the University of Iceland. She graduated with a Master's degree from the Department of Arts Education at the Iceland Academy of the Arts in 2011. Her earlier degrees are in Arts (B.A.) and philosophy. Her research interests are in art education and dissemination of art and culture. She is currently a department chair of the graduate programme Arts and Crafts at the School of Education, University of Iceland.

\section{Heimildir}

Black, J. og Browning, K. (2011). Creativity in digital art education teaching practices. Art Education, 64(5), 19-24, 33-34. Sótt af http://www.jstor.org/stable/23033959?seq=1 - page_scan_tab_contents

Craft, A. (2001). Little c Creativity. Í A. Craft, B. Jeffrey og M. Leibling (ritstjórar), Creativity in education (bls. 45-61). London: Continuum.

Craft, A. (2002). Creativity and early years education: A lifewide foundation. London: Continuum.

Dewey, J. (1934/1980). Art as experience. New York: Perigee Books.

Dewey,J. (2000). Reynsla og menntun (Gunnar Ragnarsson býddi). Reykjavík: Rannsóknarstofnun Kennaraháskóla Íslands (frumútgáfa 1938).

Eisner, E. W. (2002). The arts and the creation of mind. New Haven:Yale University.

Ho, T. K.-L. og Lin, H.-S. (2015). A web-based painting tool for enhancing student attitudes toward learning art creation. Computers \& Education, 89, 32-41. doi:10.1016/j.compedu.2015.08.015

Jones, I. og Park,Y. (2015).Virtual worlds:Young children using the internet. Í K. L. Heider og M. R. Jalongo (ritstjórar), Young children and families in the information age: Applications of technology in early childhood (bls. 3-13). doi:10.1007/97894-017-9184-7_1

Mennta- og menningarmálaráðuneytið. (2013). Ađalnámskrá grunnskóla: Almennur hluti 2011: Greinasvið 2013. Reykjavík: Höfundur.

NordBio. (2014). Biophilia - sköpun sem kennsluaðferð. Sótt af http://nordbio.org/is/verkefni/biophilia/

Ómar Örn Magnússon. (2013). Spjaldtölvur í skólastarfi [skýrsla]. Sótt af http://reykjavik.is/sites/default/files/ymis_skjol/ skjol_utgefid_efni/Spjaldtoelvur__sk_lastarfi_0.pdf

Puentedura, R. R. (2014, desember). SAMR and TPCK: A Hands-On Approach to Classroom Practice. Sótt af http:// www.hippasus.com/rrpweblog/archives/2014/12/11/SAMRandTPCK_HandsOnApproachClassroomPractice.pdf

Reykjavíkurborg. (2015). Biophilia í Reykjavík [greinargerð]. Sótt af https://reykjavik.is/sites/default/files/ymis_skjol/ skjol_utgefid_efni/greinargerd_vegna_biophilia_i_reykjavik_2011-2014-lokautgafa.pdf

Robinson, K. (2011). Out of our minds: Learning to be creative (2. útgáfa). Oxford: Capstone.

Sarpur. (2018). Menningarsögulegt gagnasafn. Sótt af www.sarpur.is

Sigríður Halldórsdóttir. (2013). Fyrirbærafræði sem rannsóknaraðferð. Í Sigríður Halldórsdóttir (ritstjóri), Handbók í aðferðafraði rannsókna (bls. 281-297). Akureyri: Háskólinn á Akureyri.

Sigríður Ólafsdóttir (2017). Sköpun í stafrenum heimi. (óútgefin meistararitgerð). Sótt af https://skemman.is/handle/1946/29203

Sólveig Jakobsdóttir, Skúlína H. Kjartansdóttir, Helga Ó. S. Pórormsdóttir og Ragnheiður L. Pálsdóttir. (2012). Spjaldtölvur i Norðlingaskóla - próunarverkefni 2012-2013. Áfangaskýrsla. Sótt af http://skrif.hi.is/rannum/files/2012/09/Afangaskyrsla_Nordlingaskoli_sept_2012_med_fylgiskjolum.pdf

Tsai, K. C. (2015). A Framework of creative education. In Education, 21(1), 137-155. Sótt af http://ineducation.ca/ ineducation/article/view/193/733

UNESCO. (2006/2007). Vegvísir fyrir listfræðslu. Heimsrádstefna um listfraðslu: Efling sköpunarkrafts á 21. öld, Lissabon, 6.-9. mars 2006 (Jón Hrólfur Sigurjónsson pýddi). Reykjavík: Félag tónlistarkennara.

Valgerður Freyja Ágústsdóttir. (2013). Upplýsingateekni í grunnskólum [skýrsla]. Sótt af http://www.samband.is/media/ skolamal/Upplysingataekni-i-grunnskolum_2013.pdf

Sigríður Ólafsdóttir, Rannveig Björk Dorkelsdóttir og Hanna Ólafsdóttir. (2018).

Sköpun í stafrænum heimi Sjónarmið myndmenntakennara.

Netla - Veftímarit um uppeldi og menntun. Menntavísindasvið Háskóla Íslands.

Sótt af http://netla.hi.is/greinar/2018/ryn/12

DOI: https://doi.org/10.24270/netla.2018.12 